DOI https://doi.org/10.18551/rjoas.2018-09.10

\title{
THE INFLUENCE OF ORGANIZATIONAL CULTURE AND WORK MOTIVATION ON EMPLOYEE PERFORMANCE OF INDUSTRIAL AND TRADE SERVICES IN AMBON CITY, INDONESIA
}

\author{
Riupassa Elisabeth*, Lecturer \\ State Polytechnic of Ambon, Indonesia \\ E-mail: riupassa1218@yahoo.com
}

\begin{abstract}
This study is a research on the scope of human resource management about organizational culture and motivation on employee performance of Industrial and Trade Services Office in Ambon City Maluku Province, this research includes explanatory research which aims to explain the influence of organizational culture variables (X1) and motivation variables (X2) on employee performance variables (Y). This study was conducted on 45 employees, with the sampling technique used was a census. Data collected through a questionnaire. Data analysis using multiple linear regression approach with the help of SPSS program for Windows 22. The results of the analysis concluded that simultaneously and partially the organizational culture and work motivation had a significant influence on the employees performance in Industrial and Trade Service of Ambon City; work motivation variables has a dominant influence on employee performance in Industrial and Trade Service Office of Ambon City. The results of this study recommend the importance of high work motivation and supported by organizational culture which is an important factor in the employees' performance of Industrial and Trade Services in Ambon City.
\end{abstract}

\section{KEY WORDS}

Organizational culture, motivation, performance, public service.

The performance of individual employees will be achieved if the employee has the motivation to work. This work motivation will be achieved if there is a willingness from her/himself and get encouragement from other parties. Encouragement will arise in employees if basic needs and others are given appropriately. Thus the existence of skilled and professional human resources could be one of the factors that determine the performance of human resources concerned (Kamau, 2015). Employee performance in this case is one of indicator that can be used in determining the success or failure of a job in terms of quantity, quality and timeliness. Performance is a manifestation of work carried out by employees in the organization concerned. Good performance is a step towards achieving organizational goals. (Nawai, 2008).

The performance in this study focused on the assessment of work result and the implementation of employee work in Industrial and Trade Service Office of Ambon City in carrying out its duties and functions. Industrial and Trade Service of Ambon City led by a Head of Service who in carrying out his duties is technically operational under and responsible to the Mayor through the Regional Secretary. The main tasks and functions of the Industrial and Trade Services are the implementers of regional autonomy in the field of industrial and trade and administratively responsible to the Mayor as an element of the regional government. Both of them have different backgrounds, namely government elements from bureaucrats and political elements, so that this will indirectly affect the performance of some employees in the Industrial and Trade Services/ Disperindag. The thing that happened in the Industrial and Trade Services / Disperindag of Ambon City was that some of its employees prioritized service to the community and ignored their obligation to comply with the provisions applicable to local government civil servants such as lack of compliance with official working hours. The official working hours are from Monday to Thursday starting at 08.00 WIB and ending at 16.00 WIB and Friday starts at 07:30 WIB ends at 15.00 WIB, but in reality some of the civil servants in the Disperindag of Ambon City 
arrived above 08.00 WIB so they did not attend the morning roll and go home before 16.00 WIB.

Based on the above conditions, it is necessary to have a suitable organizational culture to be implemented, so that it is expected that the organizational culture can help the performance of the government apparatus in running the government based on the Decree of the Minister of State Apparatus Reforms Number 4 Year 1991 on The Work Culture Correctional Guidelines which were later updated by the Decree of the Minister of State Apparatus Reforms Number 25/Kep/M.PAN/2002 on the Development of Apparatus Work Culture.

On the basis of the above, can be explained that the implementation of work culture in the Ambon City Government environment will not succeed if it is not supported by the role of employees in the organization, especially in the Industrial and Trade Services/ Disperindag of Ambon City. If employees in the organization, especially in the Industrial and Trade Services/ Disperindag of Ambon City, are dynamic and united, then the organization will be able to live and develop well. But on the contrary if humans in the organization are static, then the organization will not be able to run well.

How important the culture as an organization's identity is in accordance with the opinion of Robbins (1994: 41) that suggests several cultural functions for an organization, namely: 1) Culture acts as an organizational boundary. 2) Culture can bring a sense of identity to its members. 3) Culture can foster a broader commitment and loyalty to members of the organization. 4) Culture can increase the stability of the social system. 5) Culture functions as a mechanism for meaning and control that can shape the attitudes and behavior of its members.

Culture that is not good or negative will also affect employee performance. Employees will be lazy to work because there are no positive values that can encourage them to work better. Positive values grow from good work motivation (Dobre, 2013). Motivation is a complex problem in an organization, because the needs and desires of each member of the organization differ from one another. In the relation with the work environment, Mangkunegara (2002: 94) suggests that work motivation is defined as an influential condition that awakens, directs and maintains behaviors related to the work environment. Based on the description above, the researcher intends to conduct a study of The Influence of Organizational Culture And Work Motivation On Employee Performance Of Industrial And Trade Services In Ambon City.

Hypothesis. The research hypothesis formulated as follows:

- It is suspected that organizational culture and motivation have a significant effect on employee performance at the Industrial and Trade Services of Ambon City;

- It is suspected that motivation has a dominant influence on employee performance at the Industrial and Trade Services of Ambon City.

\section{METHODS OF RESEARCH}

This research is a type of explanatory research with analytical survey methods. This type of research aims to analyze the relationship between the influence of organizational culture variables and motivation on employee performance at the Industrial and Trade Services Office of Ambon City. In this study researchers used independent variables (X) includes $\mathrm{X}_{1}=$ Organizational Culture, $\mathrm{X}_{2}=$ Motivation, and the dependent variable $(\mathrm{Y})$ is Employee Performance.

Organizational Culture Variable $(X 1)$ the indicator namely Communication $\left(X_{1.1}\right)$, Creative and innovative $\left(X_{1.2}\right)$, Reward $\left(X_{1.3}\right)$ and Teamwork $\left(X_{1.4}\right)$. Motivation Variable $(X 2)$ the indicator namely Physiological $\left(X_{2.1}\right)$, Sense of security $\left(X_{2.2}\right)$, Social $\left(X_{2.3}\right)$, Appreciation $\left(X_{2.4}\right)$ and Self-Actualization $\left(X_{2.5}\right)$. Performance Variable $(Y)$ the indicator namely Work quantity $\left(\mathrm{Y}_{1.1}\right)$,, Work quality $\left(\mathrm{Y}_{1.2}\right)$, and Timeliness of Work $\left(\mathrm{Y}_{1.3}\right)$.

Based on the characteristics as the conditions determined by the researcher to be used as a reference as a respondent, then after obtaining information in the form of the number of employees, the population is all the Civil Servants of the Industrial and Trade 
Service of Ambon City, as many as 45 people, because the target population is quite small, so that in this study conducted census research and did not use sampling techniques. Data analysis in this study uses a multiple linear regression approach that describes the linear influence between independent variables and dependent variables. Multiple linear regression analysis model:

$$
Y=a+b_{1} X_{1}+b_{2} X_{2}+e
$$

Where: $Y=$ Employee performance; $a=$ Constants; $b_{1}, b_{2}=$ Regression Coefficients of Organizational Culture and Motivation; e = Error.

\section{RESULTS OF STUDY}

This regression analysis is used to Statistic the amount of influence between independent variables, namely organizational culture $\left(X_{1}\right)$ and work motivation $\left(X_{2}\right)$ on the dependent variable, namely employee performance $(Y)$ Hypothesis testing is carried out simultaneously and partially.

Simultaneous Hypothesis Test. To test the existence of a positive and significant influence between variables of organizational culture (X1) and variables of work motivation (X2) on the Industrial and Trade Service in Ambon City simultaneously used the Test, hypothesis testing criteria as follows:

- $\mathrm{H}_{0}$ rejected if $\mathrm{F}$ Statistic $>\mathrm{F}$ table or significance value $<0.05$;

- $\mathrm{H}_{0}$ accepted if $\mathrm{F}$ Statistic $<\mathrm{F}$ table or significance value $>0.05$.

Table 1 - Simultaneous Test ( $F$ test)

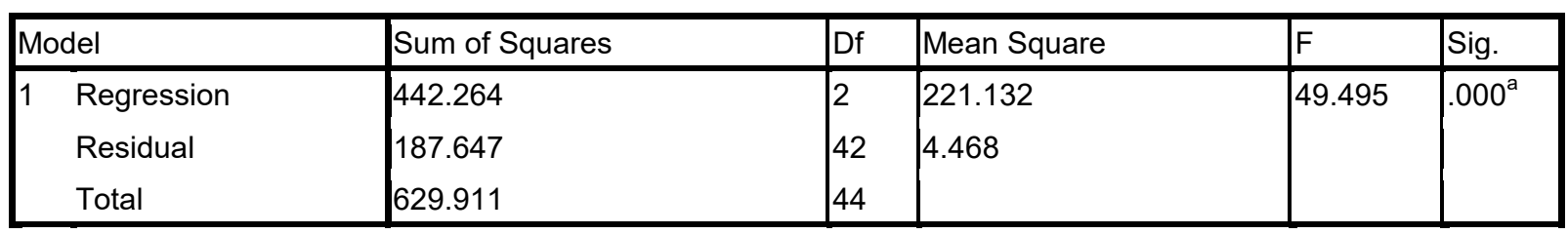

a. Predictors: (Constant), Work Motivation, Organizational Culture.

b. Dependent Variable:

Source: Primary data processed, 2018.

In Table 1, it can be explained at a 95\% confidence level $(\alpha=0,05)$ and $\mathrm{df}=2: 42$ obtained the value of $F_{\text {table }}$ equal to $=3,22$ while the value of $F$ Statistic $=49,495$, thus the value of $\mathrm{F}$ statistic $>\mathrm{F}_{\text {table }}$ so that $\mathrm{H}_{0}$ rejected or $\mathrm{H}_{\mathrm{a}}$ accepted, so it is statistically proven that there is a real influence of organizational culture and work motivation simultaneously on employee performance. Therefore the hypothesis which states that there is a positive and significant influence between organizational culture variables (X1) and work motivation variables (X2) simultaneously on improving the employees performance of the Industrial and Trade service of Ambon City can be accepted and tested statistically.

Hypothesis Testing in Partial ( $t$ test). T test to determine whether the organizational culture variable (X1) and work motivation variable (X2) partially have a significant effect on the Industrial and Trade Service in Ambon City and to determine whether the motivation variable (X2) has a dominant influence on employee performance. If $T_{\text {Statistic }}>t$ table or $\mathrm{T}_{\text {Statistic }}<-\mathrm{T}_{\text {table }}$ at a significance level of $\alpha 0.05$ then $\mathrm{H}_{0}$ rejected and $\mathrm{H}_{1}$ accepted. Meanwhile if TStatistic $<\mathrm{t}$ table or $-\mathrm{T}_{\text {Statistic }}>-\mathrm{T}$ table then $\mathrm{H}_{0}$ accepted and $\mathrm{H}_{1}$ rejected. The results of the $\mathrm{t}$ test can be shown in Table 2.

Hypothesis testing based on Table 2 can be explained:

Table 2, obtained the value of $\mathrm{T}_{\text {statistic }}$ of the leadership variable equal to 4.490 . whereas $t$ table amounted to 1.681. As $T_{\text {Statistic }}>T_{\text {table }}$ namely $4.490>1.681$ or significance value $(0.00<0.05)$ then $\mathrm{H}_{0}$ rejected and $\mathrm{H}_{1}$ accepted so it can be concluded that partially the organizational culture influences the employee performance of Industrial and Trade Service 
of Ambon City. A positive regression coefficient indicates the relation direction is parallel / in the same direction between organizational culture and employee performance. This means that the higher the organizational culture will improve the employee performance of the Industrial and Trade Service of Ambon City.

Table 2 - Partial Test (t Test)

\begin{tabular}{|c|c|c|c|c|c|c|c|}
\hline \multirow[b]{2}{*}{ Model } & \multicolumn{2}{|c|}{$\begin{array}{l}\text { Unstandardized } \\
\text { Coefficients }\end{array}$} & \multirow{2}{*}{\begin{tabular}{|l}
$\begin{array}{l}\text { Standardized } \\
\text { Coefficients }\end{array}$ \\
Beta
\end{tabular}} & \multirow[b]{2}{*}{$\mathrm{t}$} & \multirow[b]{2}{*}{ Sig. } & \multicolumn{2}{|l|}{\begin{tabular}{|l|} 
Collinearity \\
Statistics \\
\end{tabular}} \\
\hline & $B$ & Std. Error & & & & Tolerance & VIF \\
\hline 1 (Constant) & 2.067 & 2.257 & & .916 & .365 & & \\
\hline $\begin{array}{l}\text { Organizational } \\
\text { culture }\end{array}$ & .240 & .053 & .392 & 4.490 & .000 & .931 & 1.074 \\
\hline Work motivation & .363 & .049 & 645 & 7.388 & .000 & .931 & 1.074 \\
\hline
\end{tabular}

a. Dependent Variable:

Source: Primary data processed, 2018

Based on Table 2, the regression equation is obtained as follows:

$$
Y=2.067+0.240 X_{1}+0.363 X_{2}+e
$$

Hypotheses testing for work motivation variables in Table 2, obtained the value of $\mathrm{T}_{\text {Statistic }}$ equal to 7.388. Meanwhile $t$ table equal to 1.681. As $\mathrm{T}_{\text {Statistic }}>\mathrm{T}_{\text {table }}$ namely 7.388> 1.681 or significance value $(0.00<0.05)$ then $\mathrm{H}_{0}$ rejected and $\mathrm{H}_{1}$ accepted so that it can be concluded that partially the work motivation influence the employees performance of the Industrialand Trade Service of Ambon City. Positive regression coefficient indicates the relation direction is parallel / in the same direction between work motivation and employee performance. This means that the higher the employee work motivation will improve the employees performance of Ambon City Industrial and Trade Service. To find out the variables that have the most dominant influence can be seen from the value of the regression coefficient on each independent variable. The results of the analysis show that the variable of work motivation has a dominant influence compared to the organizational culture variable. Estimator value of work motivation variable is equal to 0.363 .

Determination Coefficient $\left(R^{2}\right)$. To find out the magnitude of the contribution of the independent variable to the dependent variable used the $R^{2}$ value presented in Table 3:

Table 3 - Determination Coefficient

\begin{tabular}{|c|c|c|}
\hline $\mathrm{R}$ & R Square & Adjusted R Square \\
\hline 0.806 & 0.702 & 0.688 \\
\hline
\end{tabular}

Source: Primary data processed, 2018.

The determination coefficient is used to Statistic the influence or contribution of the independent variable to the dependent variable. In Table 3, Correlation coefficient 0.702 , indicating that performance is influenced equal to $70.20 \%$ by organizational culture variables and work motivation and the remaining $29.80 \%$ is influenced by other factors outside this research. These results concluded that the ability or great diversity of leadership and motivation in explaining the performance was $70.20 \%$.

\section{DISCUSSION OF RESULTS}

The Influence of Organizational Culture on Employee Performance. The results of hypothesis testing show that there is a positive and significant influence between organizational culture on the employees' performance of the industrial and trade service of Ambon City, and it can be concluded that the higher the organizational culture, the higher the 
performance of employees. This is in accordance with the study of Henry's (2006), Dwyer, S., Richard \&Chadwick (2003), Marcoulides \& Heck (1993), Homburg \& Pflesser (2000), Lim (1995), and Novriansyah (2017) expressed that organizational culture had a positive and significant effect on employee performance. This is because organizational culture is a pattern of basic assumptions found, created or developed by a particular group with the intention that the organization can resolve, overcome problems arising from external adaptation and internal integrity that have been running quite well so that it needs to be taught and applied to new members as the right way to understand, think about and feel friends with them (Scain in Lako, 2004) in Novzriansyah (2017).

Another research supporting this research are Maslukhan (2015), Chan et al., (2004), Asree et al., (2010), Joiner (2001) which shows that organizational culture has a significant and positive effect on employee performance, it is stated that organizational culture that becomes a strong value system will foster a sense of ownership and increase morale, and this will have an impact on improving employee performance. Culture within the company or organization has the aim to develop human resources at the company or organization in order to be able to change their attitudes and behavior to improve their performance in terms of confronting the challenges of the future.

The results of the study are the same as Suryani and Budiono (2016) which shows that organizational culture has a positive and significant influence on employee performance. This is because organizational culture is the principal solution to external and internal problems that are carried out consistently by a group that then bequeaths to new members as the right way to understand, think about, and feel about related problems.

This study is different from research conducted by Haryanti, et al (2014) which states that organizational culture does not affect employee performance, but that influences employee performance is employee competence. Competence is the main variable that must be possessed by an employee to be able to carry out his work in order to complete his work in accordance with the targets set by the company (Basori, dkk, 2017).

Organizational culture is related to how employees understand the cultural characteristics of an organization, and is not related to whether employees like these characteristics or not. The importance in organizational culture seeks to measure how employees perceive their organizations. Organizations as a place where people gather, collaborate rationally and systematically, in utilizing organizational resources efficiently and effectively to achieve their intended goals. Directional cooperation is carried out by following the pattern of interaction between each individual or group in interacting in and out of the organization (Putri, 2016). The findings related to organizational culture are: (1) A strong organizational culture helps the performance of business organizations because it creates an extraordinary level in employees; (2) Strong organizational culture helps organizational performance because it provides the necessary structure and control without having to rely on rigid formal bureaucracy and which can reduce the growth of motivation and innovation (Sudirjo, et al, 2012).

The Influence of Motivation on Employee Performance. The results of hypothesis testing show that there is a positive and significant influence between motivation on the employees performance of the industrial and trade service of Ambon City, and it can be concluded that the higher the motivation given, the higher the employee's performance. This is consistent with the research of Ghaffari et al., (2017), Nabi et al., (2017), Setiawan (2015), Amalia and Fakhri (2016) which states that motivation has a positive effect on employee performance, This is because the purpose of providing the motivation according to Hasibuan (2003: 146) in Lutfi (2014) is to improve employee morale and job satisfaction, increase the employee work productivity, maintain the stability of company employees, improve the employee discipline, streamline the employee procurement, create an atmosphere and relationships good work, increase loyalty, creativity and employee participation, improve the level of employee welfare, enhance employees' sense of responsibility towards their duties and improve the efficiency of the use of tools and raw materials.

This study is supported by the opinions of Chaudhary, \& Sharma (2012) that Employee Motivation is a valuable asset that provides great value to the Organization. Motivation 
occupies an important place and position in the whole management process. This technique can be used fruitfully for encouraging workers to make positive contribution for achieving organizational objectives. Motivation is necessary as human nature needs some sort of inducement, encouragement or incentive in order to get better performance. Motivation of employee's offers may benefits to the Organisation and also to the employees. This suggests the importance of motivating employees. Motivation acts as a technique for improving the performance of employees working at different levels.

This research is supported by the research of Ali, et al (2016) which states that motivation plays an important role in employee performance, this is because motivation will encourage employees to seriously do their jobs and responsibilities. Motivation is one aspect that is very important in determining employee performance. The high and low performance of the workforce owned by a company will be strongly influenced by factors such as the work motivation of individual employees. According to Hasibuan (2005: 141) in Indarto (2015) motivation is important because motivation is the thing that causes, distributes, and supports human behavior in order to want to work hard and enthusiastically achieve optimal results.

In contrast to the research of Murti and Srimulyani (2013) which shows that motivation does not have a significant effect on employee performance, this is because humans are a social being who has desire. This desire occurs continuously and will only stop when the end of his life arrives. A need that has been satisfied is not a motivator for the perpetrator, only unmet needs will be a motivator. In line with Omolo's research (2015) which shows that motivation does not have a significant effect on employee performance, according to him that can improve employee performance is money reward.

\section{CONCLUSION}

Some conclusions can be drawn from this study, namely the organizational culture and work motivation simultaneously and partially influence the change in the employees performances of the Industrial and Trade Service of Ambon City In addition, it was found that the work motivation variable had a dominant influence on the employees performance of the Industrial and Trade Service of Ambon City. This result accommodates the importance of high work motivation that is supported by a high organizational culture that has an impact on the further employee performance.

\section{REFERENCES}

1. Ali, A., Bin, L. Z., Piang, H. J., dan Ali, Z. 2016. The impact of motivation on the employee performance and job satisfaction in it park (software house) sector of Peshawar, Pakistan. International Journal of Academic Research in Business and Social Sciences, 6(9), 297-310.

2. Amalia, S., dan Fakhri, M. 2016. Pengaruh Motivasi Kerja Terhadap Kinerja Karyawan Pada PT. Gramedia Asri Media Cabang Emerald Bintaro. Jurnal Computech \& Bisnis, 10(2), 119-127.

3. Asree, S., Zain, M., \& Rizal Razalli, M. 2010. Influence of leadership competency and organizational culture on responsiveness and performance of firms. International Journal of Contemporary Hospitality Management, 22(4), 500-516.

4. Basori, M. A. N., Prahyawan, W., dan Kamsin, D. 2017. Pengaruh Kompetensi Karyawan Dan Lingkungan Kerja Terhadap Kinerja Karyawan Melalui Motivasi Kerja Sebagai Variabel Intervening (Studi Pada PT. Krakatau Bandar Samudera). Jurnal Riset Bisnis dan Manajemen Tirtayasa, 1(2).

5. Chan, L. L., Shaffer, M. A., \& Snape, E. 2004. In search of sustained competitive advantage: the impact of organizational culture, competitive strategy and human resource management practices on firm performance. The International Journal of Human Resource Management, 15(1), 17-35. 
6. Chaudhary, N., \& Sharma, B. 2012. Impact of employee motivation on performance (productivity) in private organization. International Journal of Business Trends and Technology, 2(4), 29-35.

7. Dwyer, S., Richard, O. C., \& Chadwick, K. 2003. Gender diversity in management and firm performance: The influence of growth orientation and organizational culture. Journal of Business Research, 56(12), 1009-1019.

8. Dobre, O. I. 2013. Employee motivation and organizational performance. Review of Applied Socio-Economic Research, 5(1).

9. Ghaffari, S., Shah, I., Burgoyne, J., Mohd Nor, M., \& Salleh, J. 2017. The Influence of Motivation on Job Performance: A Case Study at Universiti Teknoligi Malaysia.

10. Haryanti, S, dkk. 2014. Pengaruh Gaya Kepemimpinan, Budaya Organisasi, Dan Kompetensi Karyawan Terhadap Kinerja Dengan Komitmen Organisasional Sebagai Variabel Mediasi (Studi Kasus Pada Rumah Sakit Islam Klaten) (Doctoral dissertation, UNS (Sebelas Maret University).

11. Henri, J. F. 2006. Organizational culture and performance measurement systems. Accounting, organizations and society, 31(1), 77-103.

12. Homburg, C., \& Pflesser, C. 2000. A multiple-layer model of market-oriented organizational culture: Measurement issues and performance outcomes. Journal of marketing research, 37(4), 449-462.

13. Indarto, A. 2015. Pengaruh motivasi terhadap kinerja karyawan PT. Duta Beton Mandiri Kecamatan Purwosari Kabupaten Pasuruan (Doctoral dissertation, Universitas Islam Negeri Maulana Malik Ibrahim).

14. Joiner, T. A. 2001. The influence of national culture and organizational culture alignment on job stress and performance: evidence from Greece. Journal of Managerial Psychology, 16(3), 229-242.

15. Kamau, F. 2015. Enhancing Job Motivation to Improve Employee Performance. Case Study Company X. Vaasan ammattikorkeakoulu University of applied sciences Degree Programme in International Business.

16. Lim, B. 1995. Examining the organizational culture and organizational performance link. Leadership \& Organization Development Journal, 16(5), 16-21.

17. Luthfi, R. I. 2014. Pengaruh Motivasi Terhadap Kinerja Karyawan (Studi Pada PT Elsiscom Prima Karya, Kantor Perwakilan Surabaya). Jurnal Administrasi Bisnis, 13(1).

18. Mangkunegara, A., P. 2002. Manajemen Sumber Daya Manusia, PT. Remaja Rosda Karya, Bandung.

19. Marcoulides, G. A., \& Heck, R. H. 1993. Organizational culture and performance: Proposing and testing a model. Organization science, 4(2), 209-225.

20. Maslukhan. 2015. Pengaruh Budaya Organisasi Terhadap Kinerja Karyawan Di Rumah Sakit Islam Surakarta. Universitas Muhammadiyah Surakarta.

21. Murti, H., \& Srimulyani, V. A. 2013. Pengaruh Motivasi Terhadap Kinerja Pegawai Dengan Variabel Pemediasi Kepuasaan Kerja Pada PDAM Kota Madiun. JRMA| Jurnal Riset Manajemen dan Akuntansi, 1(1), 10-17.

22. Nabi, M. N., Islam, M., Dip, T. M., \& Hassain, A. A. 2017. Impact of motivation on employee performances: a case study of Karmasangsthan bank Limited, Bangladesh. International Journal of Business and Management, 5(4), 57-78.

23. Nawawi. H., H. 2008. Manajemen Sumber Daya Manusia. Cetakan Ketujuh. Yogyakarta: Gadjah Mada University Press.

24. Novziransyah, N. 2017. Pengaruh Budaya Organisasi terhadap Kinerja Karyawan PT. PLN (Persero) Kantor Wilayah Sumatera Utara Medan. JUMANTIK (Jurnal IImiah Penelitian Kesehatan), 2(1), 14-25.

25. Omolo, P. A. 2015. Effect of motivation on employee performance of commercial banks in Kenya: A case study of Kenya Commercial Bank in Migori County. International journal of human resource studies, 5(2), 87-103.

26. Putri, I. S. 2016. Pengaruh Budaya Organisasi Terhadap Kinerja Pegawai Di Dinas Pendidikan Dan Kebudayaan Kota Samarinda. E-journal Administrasi Negara, 4, 1-15 
27. Setiawan, K. C. 2015. Pengaruh Motivasi Kerja Terhadap Kinerja Karyawan Level Pelaksana Di Divisi Operasi PT. Pusri Palembang. Psikis: Jurnal Psikologi Islami, 1(2), 43-53.

28. Sudirjo, F., \& Kristanto, T. 2012. Pengaruh Budaya Organisasi, Gaya Kepemimpinan dan Kepuasan Kerja Terhadap Kinerja Karyawan Dengan Komitmen Organisasional Sebagai Variabel Intervening. Jurnal Ekonomi.

29. Robbins, Stephen P., 1994. Teori Organisasi: Struktur, Desain dan Aplikasi, Alih Bahasa Jusuf Udaya, Jakarta, Arcan.

30. Suryani dan Budiono, D. S. 2016. Pengaruh Budaya Organisasi Terhadap Kinerja Karyawan Melalui Komitmen Organisasi Sebagai Variabel Intervening Pada Pt. Kerta Rajasa Raya. Jurnal Riset Ekonomi dan Manajemen, 16(1), 29-43. 